УДК 662.638

\title{
ТЕПЛОФИЗИЧЕСКОЕ ОБОСНОВАНИЕ ПИРОЛИТИЧЕСКОЙ ПЕРЕРАБОТКИ ВОЗОБНОВЛЯЕМОЙ БИОМАССЫ ЗА СЧЕТ ТЕПЛОТЫ РАЗЛОЖЕНИЯ
}

\author{
Астафьев Александр Владимирович1, \\ ava31@tpu.ru
}

\section{Табакаев Роман Борисович 1 , TabakaevRB@tpu.ru}

Языков Николай Алексеевич2,
yazykov@catalysis.ru

\author{
Заворин Александр Сергеевич1, \\ Zavorin@tpu.ru \\ 1 Национальный исследовательский Томский политехнический университет, \\ Россия, 634050, г. Томск, пр. Ленина, 30. \\ 2 Институт катализа им. Г.К. Борескова СО РАН, \\ Россия, 630090, г. Новосибирск, пр. Академика Лаврентьева, 5.
}

\begin{abstract}
Актуальность исследования обусловлена необходимостью увеличения доли использования возобновляемых источников энергии в топливно-энергетическом балансе для снижения вредного воздействия на окружающую среду.

Цель: оценка возможности пиролиза древесной биомассы и торфра за счет тепловыделения от разложения органической части сырья.

объекты: образцы торфа с двух месторождений Томской области, являющихся перспективными для разработки в энергетических целях, - Суховского и Аркадьевского, а также древесные отходы двух видов - щепа и опилки.

Методы: фризический эксперимент и диффреренциально-термический анализ. Теплотехнические характеристики древесной биомассы определены с помощью методик ГОСТ Р 56881-2016, ГОСТ 33503-2015 и ГОСТ Р 55660-2013; теплотехнические характеристики торфа - с помощью ГОСТ 11306-2013, ГОСТ 11305-2013 и ГОСТ Р 55660-2013. Теплота сгорания сырья определена на бомбовом калориметре АБК-1 (РЭТ, Россия), элементный состав определен на анализаторе Vario Micro Cube (Elementar, Германия) с учетом содержания диоксида углерода карбонатов, устанавливаемого объёмным методом согласно ГОСТ 13455-91.

Результаты. Установлены оптимальные параметры пиролитической переработки различных видов биомассы - температура пиролиза и влажность исходного сырья. Оптимальной температурой для пиролиза древесных отходов, доведенных до воздушно-сухого состояния, является $400{ }^{\circ} \mathrm{C}$, при которой суммарный тепловой эфрфект максимален и составляет 36,3 кДж/ка для опилок и 78,8 кДж/ка для щепы, для суховского торфа при $500{ }^{\circ} \mathrm{C}$ суммарный тепловой эфрфект равен 149,7 кДж/ка. Максимальные значения влажности, обеспечивающие покрытие тепловых затрат за счет теплоты экзотермических реакций, при данных температурах пиролиза составили 10 \% для древесных отходов и 14 \% для суховского торфа. Величина суммарного теплового эфффекта пиролиза аркадьевского торфра даже в сухом состоянии имеет отрицательное значение.
\end{abstract}

Ключевые слова:

Биомасса, термическая переработка, экзотермические реакции, тепловой эффрект, целлюлоза, лигнин.

\section{Введение}

Использование традиционных источников, таких как каменный уголь, нефть и природный газ, для получения энергии оказывает негативное влияние на окружающую среду. Основной проблемой являются вредные выбросы, образующиеся при сжигании сырья: согласно экспертной оценке [1], на долю энергетики приходится более половины от всех генерируемых в мире оксидов азота и серы. Постепенно происходит увеличение выбросов углекислого газа - их объём за последние 40 лет вырос в 2 раза $[2,3]$. В целом в ходе деятельности энергетического сектора образуется примерно 2/3 мировых выбросов парниковых газов. Такие колоссальные значения связаны с тем, что по разным оценкам от 78 до 86 \% глобального энергопотребления обеспечивается ископаемым топливом [3-6]. В целях снижения вредного воздей- ствия энергетики все более актуальными становятся технологии с использованием возобновляемых источников энергии (ВИЭ), способствующих предотвращению выбросов $\mathrm{CO}$ и $\mathrm{CO}_{2}, \mathrm{NO}_{x}, \mathrm{SO}_{\mathrm{x}}$. В ряде стран с тенденцией к сокращению использования ископаемых топлив и активно развивающих возобновляемую энергетику (Австрия, Дания, Швеция и др.) наблюдается положительный экологический эффект, отражающийся в снижении выбросов вредных веществ [7].

Одним из наиболее перспективных источников для энергетического использования является биомасса. В ее составе содержится малое количество серы и азота [8-10], что обеспечивает низкий уровень выбросов их оксидов при сжигании, кроме того следует отметить замкнутый цикл углекислого газа при использовании ресурсов биомассы $[9,11]$. Это приводит 
к тому, что в настоящее время биомасса является четвертым по значению топливом в мире [12], а в развивающихся странах доля ее использования составляет 35 \% в общем топливно-энергетическом балансе [13]. Однако из всех видов биомассы для производства топлива используется в основном качественная древесина, применение которой наиболее целесообразно в строительстве, архитектуре, мебельной промышленности и др. С точки зрения энергетического использования могут быть рассмотрены отходы этих видов деятельности - щепа, опилки, стружка и т. п., а также неиспользуемые для производства части дерева (ветки, кора и др.) и перезрелая древесина, представляющая собой перегниваемое сырье, накапливаемое в лесах и на местах производства. Более того, большое количество древесных отходов ухудшает экологическую обстановку и увеличивает пожароопасность лесов, в связи с чем требуется принятие мер по их утилизации. Помимо древесины, значительную долю потенциала растительной биомассы для энергетических целей составляют отходы сельского и лесного хозяйств, при этом их накопление в России увеличилось с 14,3 до 41,5 млн т за период с 2005 по 2017 гг. [14].

В ряде стран, в том числе в России, торф считается медленно возобновляемым источником энергии при условии, что прирост превышает объемы добычи В связи с тем, что годовой прирост слоя торфа составляет $\sim 1$ мм [15], а торфяные месторождения занимают в мире площадь, равную 4 млн км² [16], накапливаются большие запасы, требующие эффективного использования. При этом торфяные болота являются одним из основных естественных источников выброса в атмосферу метана $[17,18]$, оказывающего большее влияние на глобальное потепление по сравнению с $\mathrm{CO}_{2}$ [19]. Однако в настоящее время в мире добывается лишь 25 млн т торфа в год, что составляет менее $1 \%$ от мировых запасов [20]. В Российской Федерации, занимающей первое место в мире по запасам и обладающей 175 млрд т торфа (приведенного к влажности 40 \%), ежегодная добыча не превышает 1 млн т, а доля в энергобалансе страны составляет лишь $0,1-0,2 \%[6,15,16,20]$. При этом увеличение использования торфа выгодно не только с точки зрения экологии, но и с точки зрения эффективного землепользования. Рекультивация выработанных торфяных месторождений позволяет использовать земли для сельско- или лесохозяйственных нужд, кроме того, в западных странах существуют технологии повторного заболачивания с ускорением роста торфообразования [21].

Причиной низкой вовлеченности биомассы в топливно-энергетический баланс Российской Федерации является рассеянность энергии, заложенной в ее ресурсы, и связанная с этим сложность транспортировки в больших объёмах для использования на крупных энергоустановках [22]. Кроме того, биомасса обладает рядом недостатков, среди которых низкая насыпная плотность, склонность к шлакованию [23], высокая влажность (а для торфа и высокая зольность). Среднее значение влажности для древесной биомассы составляет $\sim 19 \%$ [10], а для отходов преимущественно верхней части дерева может достигать 40-50\% [24]. Влажность торфа в естественном состоянии достигает $95 \%$, при этом в его сухом остатке может содержаться до 50 \% минеральной части $[25,26]$. Это приводит к проблемам при сжигании традиционными методами $[27,28]$. Помимо этого, торф должен добываться с учетом биосферных функций болот, а также экологических последствий от разработок на окружающую среду [21]. Результатом вышеперечисленного является экономическая неэффективность и во многих случаях невозможность выработки энергии, полученной из растительной биомассы и торфа, конкурировать с выработкой из традиционных источников.

В Российской Федерации проблема использования местных ресурсов биомассы имеет особую актуальность, так как треть от производимого тепла приходится на долю децентрализованного теплоснабжения [29]. В таких районах функционируют малые котельные, работающие в основном на привозном топливе. Дороговизна газификации или поставки угля влечет за собой повышение тарифов, компенсация которого происходит из бюджета администрации района [30, 31]. Повышение эффективности энергетического использования биомассы для получения энергии на местном и региональном уровнях позволит улучшить экологическую обстановку в регионах, снизить зависимость от крупных энергетических компаний и поставок топлива, уменышив тем самым затраты на производство энергии. Например, в России насчитывается 19 субъектов, обладающих запасами торфа более 1 млрд т [20]. Накопление отходов древесины по оценкам исследователей составляет 35,5 млн м ${ }^{3}$ ежегодно, при этом бо́льшая их часть сжигается в отвалах либо вывозится на свалки для перегнивания [32]. На сегодняшний день в нескольких областях Российской Федерации введены в эксплуатацию котельные на различных видах торфа (фрезерный, топливные гранулы) [20], также в мире активно развиваются технологии изготовления топливных брикетов из различных древесных отходов $[22,33]$. Для брикетирования могут использоваться отходы древесины, локально накапливаемые на деревообрабатывающих предприятиях (опилки, щепа, кора), а также собираемые коммунальными службами (листья). При этом наиболее прочные брикеты получают из опилок или с их добавлением, так как они обладают достаточно высокой насыпной плотностью, а также содержат в своем составе лигнин, выступающий в роли связующего вещества [22].

Одним из наиболее перспективных вариантов повышения энергетической эффективности биомассы является пиролитическая переработка, в результате которой можно получить ценные для энергетики твердые, жидкие и газообразные продукты [34, 35]. На данный момент ведутся исследования пиролиза различных ресурсов биомассы, в том числе в виде смесей [36-38]. Например, совместный пиролиз торфа и опилок способствует уменьшению зольности углеродистого остатка по сравнению с исходным 
торфом, а также предотвращению зависания в реакционной зоне пиролизера более легкой фракции опилок [39].

Протекание пиролиза зависит от выбора параметров процесса. В ходе медленного пиролиза (скорость нагрева от 6 до $60 \mathrm{~K} /$ мин [40]) преимущественным выходом обладает твердый продукт (углеродистый остаток или полукокс), который находит применение во многих областях промышленности. Основными потребителями являются химическая промышленность, вырабатывающая активированный уголь и сорбенты по улавливанию различных вредных выбросов $[41,42]$, а также энергетическая отрасль - более $50 \%$ древесного угля используется в качестве топлива [12], например, в виде исходного вещества для формования брикетов [43].

При высоких скоростях нагрева (до $1000 \mathrm{~K} / \mathrm{c}$ ) преобладает выход жидких продуктов (до 80 \% от массы сухого сырья) [44]. Несмотря на большое количество химически ценных компонентов в пиролизной жидкости, выделение каждого из них трудозатратно и экономически неэффективно. В связи с этим самый распространенный вариант использования пиролизной жидкости - замена котельному топливу. При этом на сегодняшний день около 75 \% биотоплива в мире получают из древесины [22]. Перспективным направлением является производство продуктов для очистки дымовых газов от вредных выбросов. Компанией Dynamotive разработан органический кальциевый продукт под названием BioLime ${ }^{\text {TM }}$ для улавливания из газоходов котла оксидов азота и серы, который представляет собой раствор жидких продуктов пиролиза биомассы с известью и обладает большей эффективностью по сравнению с известью [45].

Пиролизный газ является среднекалорийным, так как состоит в основном из негорючего компонента $\mathrm{CO}_{2}$, в связи с чем применяется для поддержания процесса пиролиза или получения тепла в этом же производстве [12]. Оптимальной температурой пиролиза для получения газа с наибольшей теплотой сгорания является $500{ }^{\circ} \mathrm{C}$, так как концентрация в нем водорода и углекислого газа невелика по сравнению с концентрацией метана [46].

Предпосылкой к обоснованию применения пиролиза в энергетике является возможность проведения процесса за счет собственных тепловых эффектов разложения. Часть исследователей отмечает протекание экзотермических реакций в отдельных видах органического сырья после нагрева без доступа воздуха до $200{ }^{\circ} \mathrm{C}[46,47]$. В связи с этим целью настоящей работы является оценка возможности пиролиза древесной биомассы и торфа за счет тепловыделения от разложения органической части сырья.

\section{Методика исследования}

Объект исследования. В работе рассмотрены образцы торфа с двух месторождений Томской области, являющихся перспективными для разработки в энергетических целях [48] - Суховского ( 55,5 млн т) и Аркадьевского ( 3 млн т), а также древесные отходы двух видов - щепа из различных древесных пород (сосна, береза, осина и др.) и сосновые опилки, характерные для Сибири в целом. Характеристики сырья исследованы после достижения воздушно-сухого состояния в лабораторных условиях. Зольность и влажность древесных отходов определены согласно ГОСТ Р 56881-2016 и ГОСТ 33503-2015, зольность и влажность торфа - согласно ГОСТ 11306-2013 и ГОСТ 11305-2013. Выход летучих веществ определен согласно ГОСТ Р 55660-2013, теплота сгорания - с помощью бомбового калориметра АБК-1 (РЭТ, Россия). Элементный состав определен на анализаторе Vario Micro Cube (Elementar, Германия) с учетом содержания диоксида углерода карбонатов, устанавливаемого объёмным методом согласно ГОСТ 13455-91.

Дифференциально-термический и гравиметрический анализ. Термогравиметрический и дифференциально-термический анализы рассматриваемых видов сырья выполнены на микротермоанализаторе STA 449C (Netzsch, Германия) в инертной среде (гелий) с целью имитации условий пиролитической переработки, а также исключения влияния окислительных реакций на результаты исследования. Для анализа использованы пробы, предварительно доведенные до воздушно-сухого состояния. Скорость нагрева составила $10{ }^{\circ} \mathrm{C}$ в минуту, что соответствует средней скорости нагрева согласно ГОСТ 3168-93, используемого для определения выхода продуктов полукоксования при медленном типе пиролиза. Медленный тип пиролиза выбран в связи с тем, что в его результате образуется преимущественно углеродистый остаток, а образование полукокса сопровождается реакциями с выделением теплоты $[49,50]$. Температурный диапазон эксперимента составил от 20 до $600{ }^{\circ} \mathrm{C}$. Конечная температура выбрана в связи с тем, что до этого значения в сырье завершаются все экзотермические реакции [46].

Оценка тепловых затрат прочесса пиролиза. Величина тепловых затрат, необходимых для осуществления пиролиза, рассчитывалась по методике, представленной в [51], согласно которой теплота, подведенная к сырью, расходуется на сушку $\left(Q_{1}\right)$, нагрев до температуры $\left(t_{1}\right)$ начала активного разложения сырья $\left(Q_{2}\right)$, образование углеродистого остатка $\left(Q_{3}\right)$ и потери с летучими продуктами пиролиза - газом, парами пирогенетической воды и смолы $\left(Q_{4}\right)$. За критерий автотермичности принято условие, при котором теплоты экзотермических реакций, протекающих в сырье во время нагрева, достаточно для компенсации вышеперечисленных затрат. Температурные интервалы

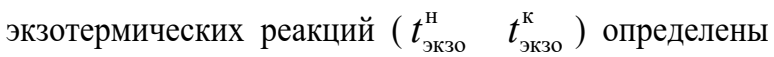
из пиков на кривой ДТА; величина тепловых эффектов на сухую массу сырья $\left(Q_{\text {тэ}}\right)$ - путем сопоставления площадей эндотермического и экзотермического пиков на кривых ДТА. Величина суммарного теплового эффекта $\left(\sum Q\right)$ отражает разницу между тепловыделением от протекания экзотермических реакций $\left(Q_{\mathrm{T \ni}}\right)$ и тепловыми затратами $\left(Q_{1-4}\right)$. Значения удельной теплоемкости $\left(C_{p b}\right)$ определены на анализаторе температуропроводности DLF-1200 (TA Instruments, США), подробная методика представлена в [51]. Теп- 
лоёмкость углеродистого остатка принята равной 0,707 кДж/(кг·К) для торфа [52] и 1,7 кДж/(кг·К) для древесных отходов [53].

\section{Обсуждение результатов}

В табл. 1 представлены результаты определения теплотехнических характеристик исследуемого сырья. Следует отметить, что древесные отходы обладают высокой для биомассы теплотой сгорания, торф из-за высокой зольности характеризуется низким ее значением. Высокий выход летучих у всех видов рассматриваемого сырья говорит о слабой термической стойкости органической части сырья и низкой температуре воспламенения, что подтверждается литературными данными. Наименее стойкие к нагреву компоненты древесины, такие как целлюлоза и ксилан, начинают разлагаться уже при температуре $150{ }^{\circ} \mathrm{C}$ [12]. Температура начала выхода летучих из торфа составляет $\sim 100{ }^{\circ} \mathrm{C}$ [54], а высушенный торф может самовозгораться даже при отрицательных температурах (вплоть до $-15^{\circ} \mathrm{C}$ ) [25].

Таблица 1. Теплотехнические характеристики биомассы Table 1. Thermotechnical characteristics of biomass

\begin{tabular}{|c|c|c|c|c|}
\hline $\begin{array}{c}\text { Характеристика } \\
\text { Characteristic }\end{array}$ & \begin{tabular}{|c|}
$\begin{array}{c}\text { Суховской } \\
\text { торф } \\
\text { Sukhovskoy } \\
\text { peat }\end{array}$ \\
\end{tabular} & $\begin{array}{c}\text { Аркадьевский } \\
\text { торф } \\
\text { Arkadievsky } \\
\text { peat } \\
\end{array}$ & $\begin{array}{l}\text { Опилки } \\
\text { Sawdust }\end{array}$ & $\begin{array}{l}\text { Щепа } \\
\text { Chips }\end{array}$ \\
\hline $\begin{array}{l}\text { Влажность/Moisture, } \\
W^{a}, \%\end{array}$ & 9,9 & 9,9 & 7,0 & 7,8 \\
\hline $\begin{array}{l}\text { Зольность на сухую массу } \\
\text { Ash on dry basis, } A^{d}, \%\end{array}$ & 22,8 & 25,4 & 1,6 & 1,9 \\
\hline $\begin{array}{l}\text { Выход летучих веществ } \\
\text { Yield of volatile substances, } \\
V^{d a f}, \%\end{array}$ & 74,8 & 70,7 & 83,4 & 81,5 \\
\hline $\begin{array}{l}\text { Низшая теплота } \\
\text { сгорания, МДж/кг } \\
\text { Lower calorific value, } Q_{i}^{r} \text {, } \\
\text { MJ/kg }\end{array}$ & 11,8 & 11,4 & 18,1 & 17,1 \\
\hline $\begin{array}{l}\text { Элементный состав } \\
\text { на сухую беззольную массу } \\
\text { Elemental composition per } \\
\text { combustible mass, \% }\end{array}$ & & & & \\
\hline$C^{d a f}$ & 52,06 & 53,11 & 52,50 & 50,32 \\
\hline$H^{\text {daf }}$ & 6,31 & 5,90 & 6,58 & 6,05 \\
\hline$N^{d a f}$ & 3,58 & 3,60 & 0,22 & 0,24 \\
\hline$S^{d a f}$ & 0,20 & 0,14 & 0,00 & 0,00 \\
\hline$O^{\text {daf }}$ & 37,85 & 37,25 & 40,70 & 43,39 \\
\hline $\begin{array}{l}\text { Содержание диоксида } \\
\text { углерода карбонатов } \\
\text { Carbon dioxide content in the } \\
\text { carbonates, }\left(\mathrm{CO}_{2}\right)_{\mathrm{d}}^{\mathrm{M}}, \%\end{array}$ & 9,82 & 9,11 & - & - \\
\hline
\end{tabular}

Результаты дифференциально-термического анализа представлены на рис. 1. Согласно полученным кривым определены значения величин, необходимых для расчета тепловых затрат (табл. 2). Температура полного испарения влаги $\left(t_{d}\right)$ соответствует окончанию эндотермического пика на кривой ДТА, значение влажности $\left(W^{a}\right)$ принято равным убыли массы при этой температуре. Температура начала разложения сырья $\left(t_{1}\right)$ соответствует началу увеличения скорости убыли массы.

Расчёт тепловых затрат проведен для нескольких температур из интервала $t_{1}-t_{\mathrm{p}}$. Величина массы полученного углеродистого остатка при температуре $t_{1}$ вычислялась путем вычитания из общей массы сырья значения влажности, выход летучих веществ в этот момент принимался равным нулю. Для выбранных температур окончания пиролиза величина массы углеродистого остатка определялась по кривой ТГ (рис. 1), а выход летучих продуктов составлял разницу между значениями массы углеродистого остатка при температурах $t_{1}$ и $t_{\mathrm{p}}$.

Таблица 2. Исходные данные для расчета тепловых затpam

Table 2. Initial data for calculation of thermal consumptions

\begin{tabular}{|c|c|c|c|c|c|c|}
\hline \multirow[b]{2}{*}{$\begin{array}{c}\text { Топливо } \\
\text { Fuel }\end{array}$} & \multicolumn{6}{|c|}{ Характеристика/Characteristic } \\
\hline & $\begin{array}{l}t_{d,} \\
{ }^{\circ} \mathrm{C}\end{array}$ & $\begin{array}{c}W^{a}, \\
\%\end{array}$ & $\begin{array}{l}t_{1} \\
{ }^{\circ} \mathrm{C}\end{array}$ & $\begin{array}{c}C_{p b}, \\
\kappa Д ж / \kappa \Gamma ~ \\
\mathrm{~kJ} / \mathrm{kg}\end{array}$ & $\begin{array}{c}t_{\text {экзо }}^{\mathrm{H}} t_{\text {экзо }}^{\mathrm{K}} \\
t_{\mathrm{exo}}^{\mathrm{s}} \quad t_{\mathrm{exo}}^{\mathrm{f}},{ }^{\circ} \mathrm{C}\end{array}$ & $\begin{array}{c}Q_{\mathrm{T}} / Q_{\mathrm{TE}}, \\
\text { кДж/кГ } \\
\mathrm{kJ} / \mathrm{kg}\end{array}$ \\
\hline $\begin{array}{l}\text { Опилки } \\
\text { Sawdust }\end{array}$ & 110 & 8 & 230 & 2,377 & $240-550$ & 1062 \\
\hline Щепа/Chips & 110 & 6 & 230 & 2,292 & $240-570$ & 1103 \\
\hline \begin{tabular}{|l|} 
Аркадьев- \\
ский торф \\
Arkadievsky \\
peat
\end{tabular} & 105 & 6 & 180 & 1,486 & $200-570$ & 393 \\
\hline $\begin{array}{l}\text { Суховской } \\
\text { торф } \\
\text { Sukhovskoy } \\
\text { peat }\end{array}$ & 105 & 7 & 180 & 1,624 & $200-530$ & 862 \\
\hline
\end{tabular}

Результаты расчетов тепловых затрат представлены в табл. 3, 4. Следует отметить, что значение теплоты, необходимое для нагрева до температуры начала активного разложения сырья $\left(Q_{2}\right)$ для древесных отходов вдвое больше, чем для торфа. Это связано с большей теплоемкостью древесины, что обусловлено химическим составом сырья - древесина содержит в своем составе большее количество органических веществ (табл. 1), которые обладают более высоким значением удельной теплоемкости по сравнению с минеральными $[55,56]$, содержание которых выше в торфе. Кроме того, влияние на величину $Q_{2}$ оказывает различие в компонентных составах торфа и древесных отходов. Древесина примерно на треть состоит из лигнина [57] по сравнению с торфом, содержащим менее $10 \%$ [58]. Это подтверждается результатами материального баланса различных видов биомассы [59], из которых видно, что максимальный выход смолы, являющейся продуктом термического разложения лигнина [39], свойственен древесным отходам. Так как лигнин является наиболее термически стойким компонентом, укрепляющим стенки клеток растений $[39,60]$, то для начала активного разложения древесного сырья требуется нагрев до большей температуры. В связи с этим $t_{1}$ при переработке древесных отходов на $50{ }^{\circ} \mathrm{C}$ выше, чем аналогичная величина при переработке торфа (рис. 1, табл. 2). Щепа и опилки начинают активно разлагаться после нагрева до $230{ }^{\circ} \mathrm{C}$ (рис. 1 в, г) и до $400{ }^{\circ} \mathrm{C}$ теряют основную часть массы. Это может быть связано с тем, что в данном температурном диапазоне совместно разлагаются все основные компоненты древесины - целлюлоза, гемицеллюлоза и лигнин [61]. Выход летучих из торфа начинается практически сразу после удале- 
ния влаги, после чего происходит равномерная потеря массы до окончания нагрева (рис. 1, $a$, б). Величина теплоты на образование углеродистого остатка $\left(Q_{3}\right)$ при переработке древесины также имеет большее значение по сравнению с торфом, так как выше теп- лоемкость углеродистого остатка. Потери с летучими продуктами $\left(Q_{4}\right)$ до температуры $300{ }^{\circ} \mathrm{C}$ больше при пиролизе торфа, при нагреве выше этой температуры больше выход летучих и, соответственно, теплота, уходящая с ними, для щепы и опилок.

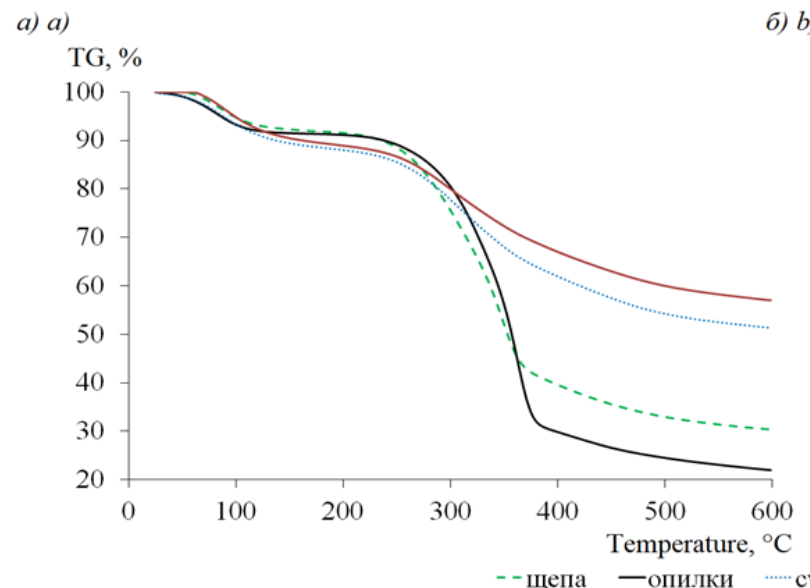

б) b)

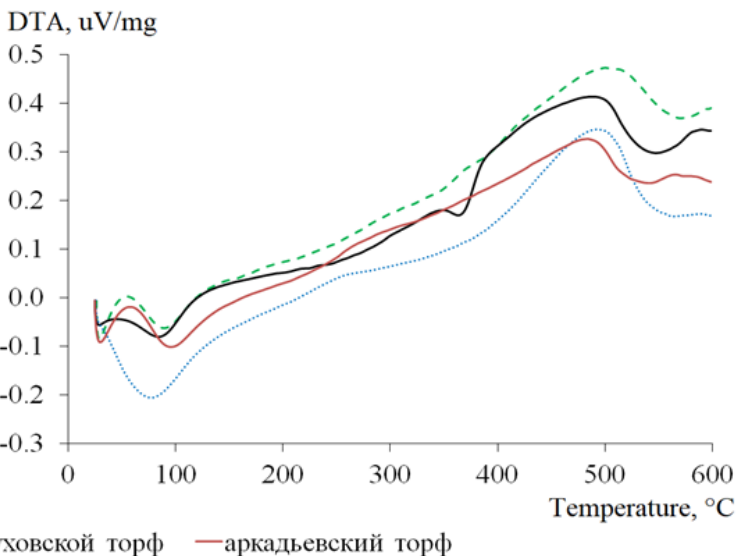

Pис. 1. Результаты термогравиметрического (а) и дифференииально-термического (б) анализа исследуемого сырья

Fig. 1. Results of thermogravimetric (a) and differential thermal (b) analysis of raw material

Таблица 3. Тепловые затраты на осуществление пиролиза древесных отходов (опилок/щеепы)

Table 3. Thermal consumptions for pyrolysis of wood waste (sawdust/chips)

\begin{tabular}{|c|c|c|c|c|}
\hline \multirow{2}{*}{$\begin{array}{c}\text { Температура } \\
\text { окончания } \\
\text { разложения } \\
\text { Temperature of } \\
\text { decomposition } \\
\text { ending, } t_{\mathrm{p}},{ }^{\circ} \mathrm{C}\end{array}$} & \multicolumn{4}{|c|}{$\begin{array}{c}\text { Тепловые затраты на осуществление пиролиза, } \\
\text { кДж/кг } \\
\text { Thermal consumptions for pyrolysis, kJ/kg }\end{array}$} \\
\hline & $Q_{1}$ & $Q_{2}$ & $Q_{3}$ & $Q_{4}$ \\
\hline 300 & $210,8 / 158,1$ & $459,3 / 452,5$ & $93,3 / 99,0$ & $5,2 / 3,9$ \\
\hline 350 & $210,8 / 158,1$ & $459,3 / 452,5$ & $137,0 / 138,1$ & $33,0 / 39,6$ \\
\hline 380 & $210,8 / 158,1$ & $459,3 / 452,5$ & $143,1 / 160,6$ & $71,7 / 63,1$ \\
\hline 400 & $210,8 / 158,1$ & $459,3 / 452,5$ & $159,5 / 178,6$ & $85,1 / 76,1$ \\
\hline 420 & $210,8 / 158,1$ & $459,3 / 452,5$ & $176,1 / 197,4$ & $98,7 / 88,5$ \\
\hline 450 & $210,8 / 158,1$ & $459,3 / 452,5$ & $200,4 / 225,0$ & $120,1 / 108,2$ \\
\hline 500 & $210,8 / 158,1$ & $459,3 / 452,5$ & $241,8 / 269,7$ & $156,4 / 143,9$ \\
\hline $550 / 570$ & $210,8 / 158,1$ & $459,3 / 452,5$ & $282,8 / 334,1$ & \begin{tabular}{|l}
$194,6 / 194,3$ \\
\end{tabular} \\
\hline
\end{tabular}

Таблица 4. Тепловые затраты на осуществление пиролиза торфа (суховского/аркадьевского)

Table 4. Thermal consumptions for pyrolysis of peat (sukhovskoy/arkadievsky)

\begin{tabular}{|c|c|c|c|c|}
\hline \multirow{2}{*}{$\begin{array}{c}\text { Температура } \\
\text { окончания раз- } \\
\text { ложения } \\
\text { Temperature of } \\
\text { decomposition } \\
\text { ending, } t_{\mathrm{p}},{ }^{\circ} \mathrm{C}\end{array}$} & \multicolumn{4}{|c|}{$\begin{array}{c}\text { Тепловые затраты на осуществление пиролиза, } \\
\text { кДж/кг } \\
\text { Thermal consumptions for pyrolysis, kJ/kg }\end{array}$} \\
\hline & $Q_{1}$ & $Q_{2}$ & $Q_{3}$ & $Q_{4}$ \\
\hline 300 & \begin{tabular}{|l|}
$183,0 / 156,8$ \\
\end{tabular} & $241,7 / 223,6$ & $67,3 / 69,4$ & $14,2 / 12,9$ \\
\hline 350 & $183,0 / 156,8$ & $241,7 / 223,6$ & $90,0 / 94,1$ & $33,6 / 29,2$ \\
\hline 400 & 183, & $241,7 / 223,6$ & $112,1 / 117,7$ & $55,7 / 49,1$ \\
\hline 450 & 183 & $241,7 / 2$ & $133,6 / 140,9$ & $80,8 / 7$ \\
\hline 480 & $183,0 / 156,8$ & $241,7 / 223,6$ & $146,0 / 154,5$ & $97,9 / 85,9$ \\
\hline 500 & $183,0 / 156,8$ & $241,7 / 223,6$ & $154,6 / 163,8$ & $108,4 / 95,6$ \\
\hline $530 / 570$ & $183,0 / 156,8$ & $241,7 / 223,6$ & $168,0 / 196,3$ & $123,7 / 130,0$ \\
\hline
\end{tabular}

Основываясь на результатах расчета (табл. 3,4$)$ и ДТА-анализа (рис. 1) построены температурные зависимости суммарных тепловых эффектов процесса пиролиза исследуемого сырья (рис. 2). Теплового эффекта при пиролизе аркадьевского торфа из-за его малой величины недостаточно для покрытия тепловых затрат во всем рассматриваемом температурном интервале. Наибольшие значения теплоты в ходе переработки древесины можно получить при температуре $400{ }^{\circ} \mathrm{C}-36,3$ кДж/кг для опилок и 78,8 кДж/кг для щепы. Для суховского торфа максимальное значение $\left(149,7\right.$ кДж/кг) достигается при $500{ }^{\circ} \mathrm{C}$. Это объясняется разным механизмом разложения древесного сырья и торфа и протекания экзотермических реакций в ходе процесса. Как видно из рис. 2, $a$, величина теплового эффекта пиролиза древесины резко увеличивается при нагреве до $400{ }^{\circ} \mathrm{C}$, после чего изменяется незначительно. Выделение теплоты при разложении суховского торфа происходит практически линейно (рис. 2, б) в интервале всего экзотермического пика разложения сырья (200-530 $\left.{ }^{\circ} \mathrm{C}\right)$.

Различия связаны с тем, что основные экзотермические реакции разложения древесины заканчиваются до температуры $400{ }^{\circ} \mathrm{C}$, после чего в величину теплового эффекта вносит вклад лишь распад лигнина, а масса сырья изменяется незначительно. Торф обладает более сложным составом [25], в который в зависимости от типа образования и степени разложения входят легкогидролизуемые вещества (25-47 \%), гуминовые и фульвовые кислоты (31-68 \%), а также в меньшем количестве битумы, водорастворимые вещества, лигнин и целлюлоза $[58,62,63]$. В связи с многокомпонентным составом разложение сырья происходит равномерно во всем исследуемом температурном интервале (рис. 1, б). При этом практически все компоненты, входящие в состав торфа (за исключением битумов), разлагаются с выделением теплоты: до $400{ }^{\circ} \mathrm{C}$ гуминовые кислоты, водорастворимые и легкогидролизуемые соединения, после $400{ }^{\circ} \mathrm{C}$ - лигнин и негидролизуемый 
остаток [64]. Однако из-за низинного типа образования суховского торфа [65] и, как следствие, высокой зольности $(22,8 \%)$ величина теплового эффекта составляет меньшее значение по сравнению с древесными отхо- дами. Несмотря на это, из-за меньших тепловых затрат, необходимых для осуществления пиролиза суховского торфа, величина $\sum Q$ имеет большее значение, чем для пиролиза древесных отходов.

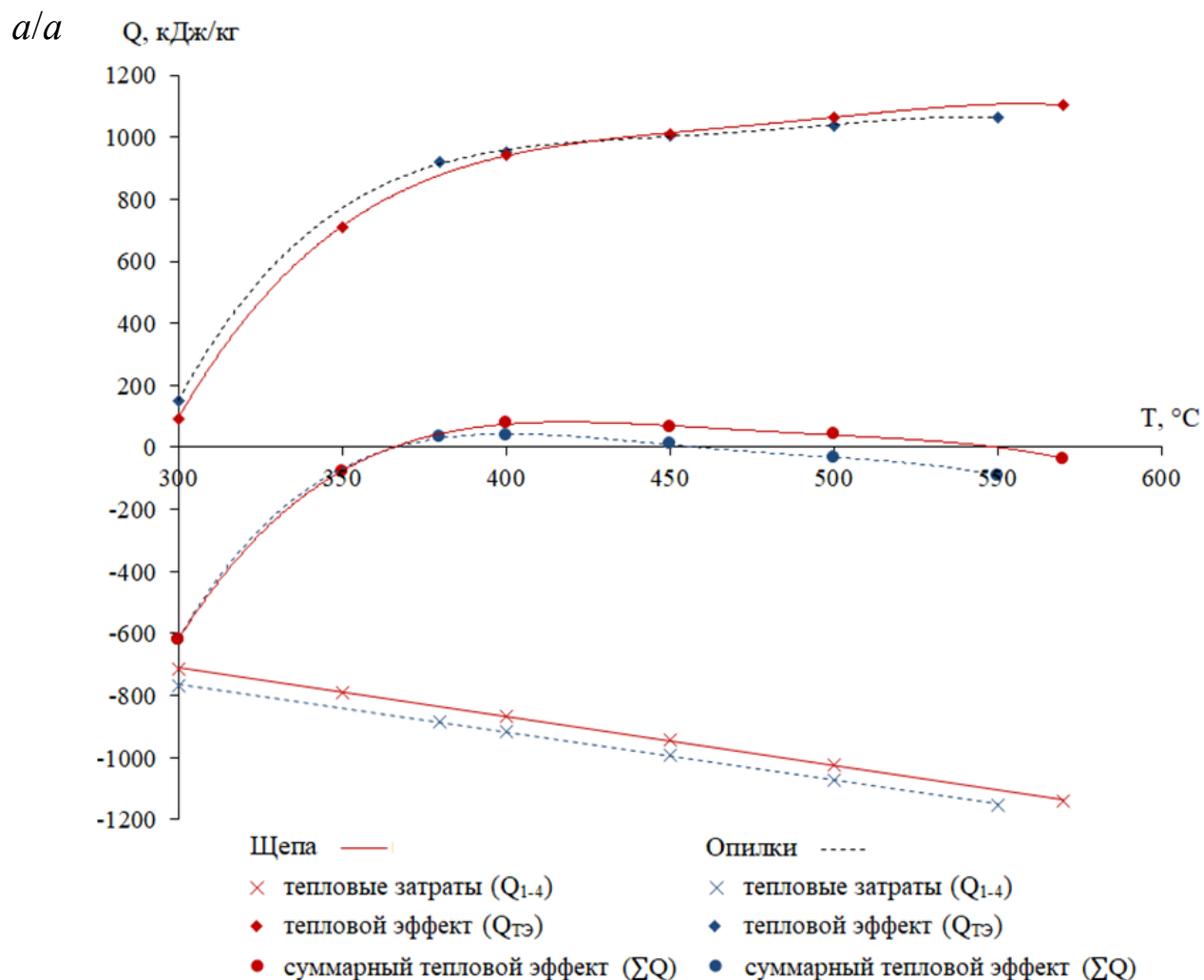

$\sigma / b$

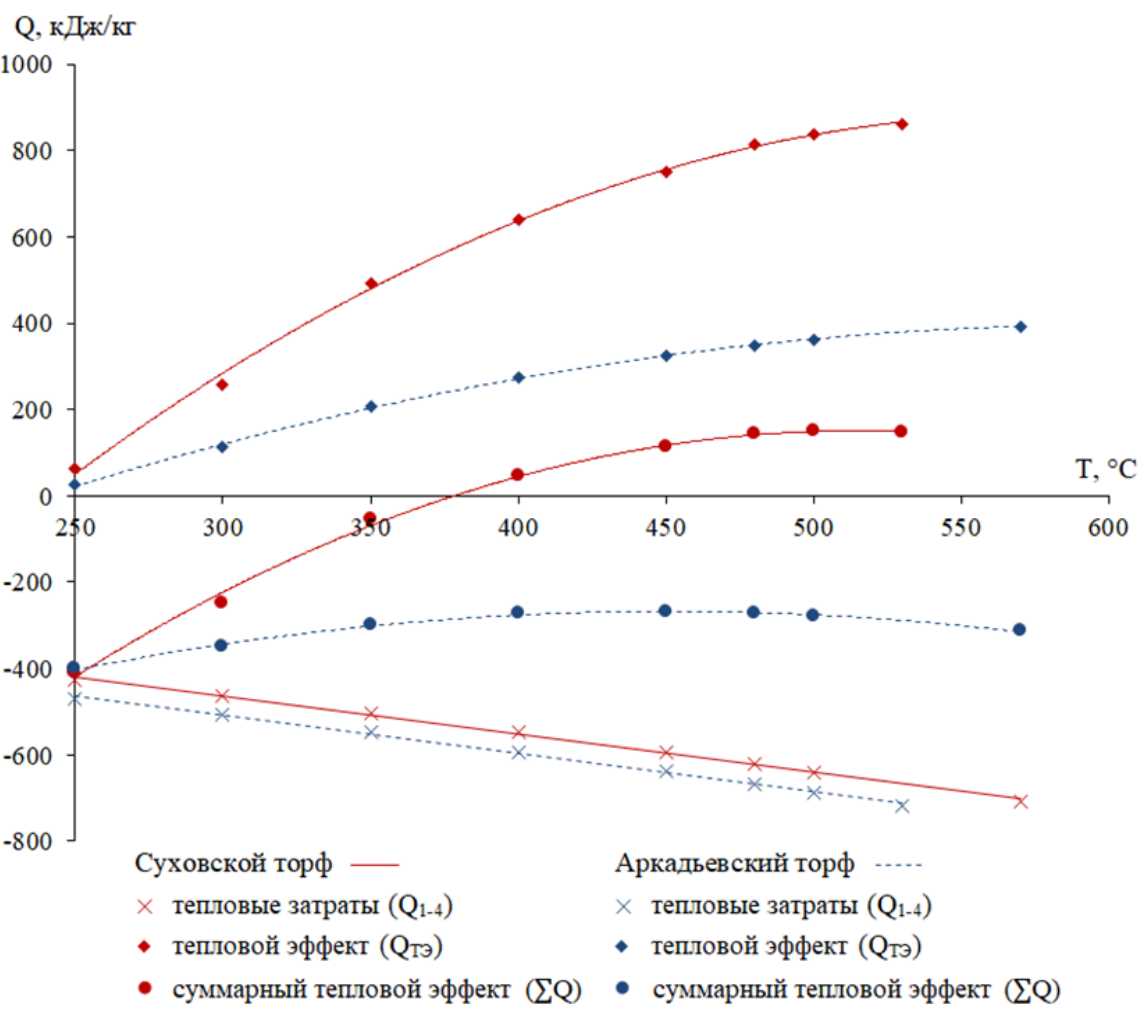

Рис. 2. Зависимость суммарного теплового эффекта пиролиза от температуры процесса для древесных отходов (a) и торфа (б) при значениях влажности $W^{a}$

Fig. 2. Dependence of the total heat effect from pyrolysis on temperature for wood waste (a) and peat (b) at moisture values $W^{a}$ 
Ранее в работе [59] показано, что немаловажным фактором, оказывающим влияние на протекание процесса пиролиза, является влажность перерабатываемого сырья. Предварительная сушка биомассы позволяет варьировать выход продуктов пиролиза - при уменьшении влажности акцент смещается от образования жидких и газообразных к твердым продуктам $[40,66]$. Исследование оптимальных значений влажности, при которых пиролитическая переработка биомассы наиболее эффективна, упоминается во многих работах [9-11, 40, 65, 66]. Согласно [40], биомассу с содержанием влажности выше 30 \% неэффективно использовать в целях пиролиза, так как при ее переработке уменьшается скорость нагрева, что приводит к увеличению времени протекания процесса. Более того, использование высоковлажной биомассы увеличивает расход топлива и снижает КПД пиролизных установок [66].

Для изучения горения топлив за счет тепловыделения от разложения наиболее наглядным методом считается треугольник Таннера, связывающий три ключевых параметра в составе сырья - содержание горючих веществ, влажность и зольность. Так, орга-

Суммарный тепловой эффект $\mathrm{Q}$, кДж/кт

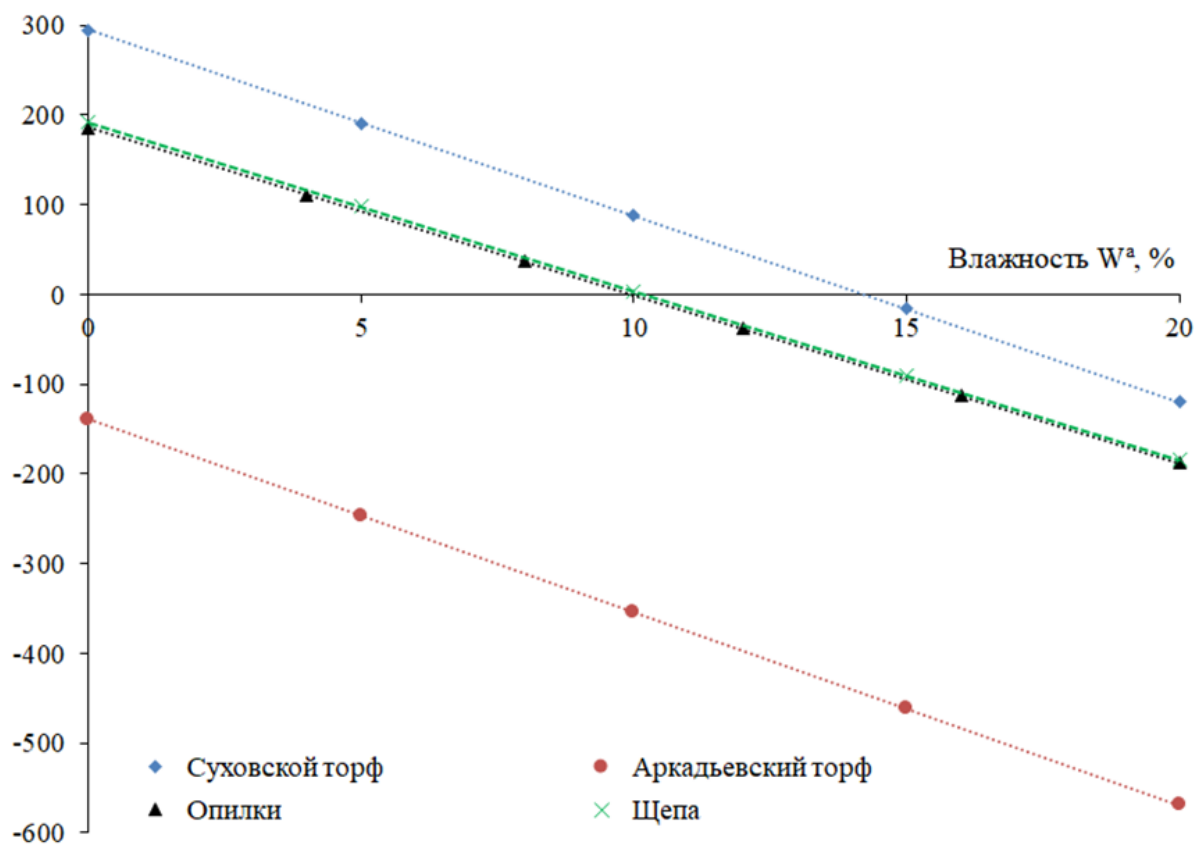

Рис. 3. Зависимость суммарного теплового эффекта пиролиза от влажности исходного сырья

Fig. 3. Dependence of the total heat effect on moisture of raw material

\section{Заключение}

Результаты расчета тепловых затрат и оценки тепловых эффектов разложения сырья позволили определить оптимальные параметры пиролитической переработки различных видов биомассы - температуру пиролиза и влажность исходного сырья. Наиболее перспективным является медленный тип пиролиза, позволяющий получить максимальный выход углеродистого остатка, образование которого сопровождается реакциями с выделением теплоты. ническое топливо может самопроизвольно поддерживать процесс горения без подвода внешней теплоты при содержании в составе более $25 \%$ горючих, влажности и зольности - менее 50 и 60 \% [67]. Аналогично данному методу могут быть получены значения для пиролитической переработки за счет собственного тепловыделения. В связи с чем при температурах, позволяющих достичь максимального суммарного теплового эффекта, произведена оценка влияния влажности на возможность организации процесса пиролиза в автотермическом режиме. Полученные результаты представлены на рис. 3 .

Тепловые затраты пиролиза суховского торфа могут быть покрыты при влажности исходного сырья менее $14 \%$, для древесных отходов значение максимальной влажности для теоретически возможной переработки за счет собственного тепловыделения составляет $\sim 10 \%$. Аркадьевский торф даже в сухом состоянии невозможно переработать за счет тепловых эффектов разложения, в связи с чем необходимо покрытие части тепловых затрат с помощью внешнего источника. Один из вариантов - использование теплоты сгорания получаемых в ходе пиролиза продуктов.

Оптимальной температурой для пиролиза древесных отходов является $400{ }^{\circ} \mathrm{C}$, при которой суммарный тепловой эффект максимален и составляет 36,3 кДж/кг для опилок и 78,8 кДж/кг для щепы, для суховского торфа при $500{ }^{\circ} \mathrm{C}$ суммарный тепловой эффект равен 149,7 кДж/кг. Бо́льшая величина для суховского торфа связана с тем, что тепловые затраты на организацию его пиролитической переработки приблизительно в 1,5 раза меньше по сравнению с переработкой древесины. Это связано с меньшей теплоемкостью исходного торфа и углеродистого остатка 
из него, а также более низким выходом летучих продуктов. Максимальные значения влажности, обеспечивающие покрытие тепловых затрат за счет теплоты экзотермических реакций, при оптимальных температурах пиролиза составили 10 \% для древесных отходов и $14 \%$ для суховского торфа. Процесс пиролиза даже сухого аркадьевского торфа невозможно организовать за счет тепловых эффектов разложения в связи с малой величиной тепловыделения (393 кДж/кг) и высокой зольностью $(25,4$ \%). В качестве внешнего источника для покрытия тепловых затрат может быть использована теплота от сжигания продуктов пиролиза или части исходного сырья.

\section{СПИСОК ЛИТЕРАТУРЫ}

1. World Energy Outlook Special Report. Energy and Air Pollution. - Paris: International Energy Agency Publ., 2016. - 9 p.

2. The proportionality of global warming to cumulative carbon emissions / H.D. Matthews, N.P. Gillett, P.A. Stott, K. Zickfeld // Nature. - 2009. - V. 459. - P. 829-832.

3. Сидорович В. Мировая энергетическая революция. Как возобновляемые источники энергии изменят наш мир. - М.: Альпина Паблишер, 2015. - 208 c

4. Попель О.С., Фортов В.Е. Возобновляемая энергетика в современном мире. - М: Издательский дом МЭИ, 2015. - 450 с.

5. Statistics of International Energy Agency. URL https://www.iea.org/statistics/?country=WORLD\&year=2016\&cat egory=Energy $\% 20$ supply\&indicator=TPESbySource\&mode=chart \&dataTable=BALANCES (дата обращения: 23.08.2019).

6. Тимохов В.М., Жизнин С.З. Ресурсы мировой энергетики // Вестник Московского гуманитарно-экономического института. - 2018. - № 2. - С. 115-124.

7. Ермоленко Г.В. и др. Справочник по возобновляемой энергетике европейского союза. - М.: Институт энергетики НИУ ВШЭ, 2016. $-96 \mathrm{c}$

8. Dhyani V., Bhaskar T. A comprehensive review on the pyrolysis of lignocellulosic biomass // Renewable energy. - 2018. - V. 129. P. 695-716.

9. A review on biomass as a fuel for boilers / R. Saidur, E.A. Abdelaziz, A. Demirbas, M.S. Hossaina, S. Mekhilef // Renewable and sustainable energy reviews. -2011 . - V. 15. - P. 2262-2289.

10. An overview of the chemical composition of biomass S.V. Vassilev, D. Baxter, L.K. Andersen, C.G. Vassileva // Fuel. 2010 - V. 89. - P. 913-933.

11. McKendry P. Energy production from biomass. P. 1: overview of biomass // Bioresource Technology. - 2002. - V. 83. - P. 37-46.

12. Терентьева Э.П., Удовенко Н.К., Павлова Е.А. Комплексная химическая переработка древесины. - СПб.: ВШТЭ СПбГУПТД, 2016. - 74 c.

13. Вафина Ю.А. Энергосбережение за счет использования альтернативных источников энергии и вторичных энергоресурсов: Россия и мировой опыт // Вестник Казанского технологического университета. - 2012. - Т. 15. - № 9. - С. 265-272.

14. Лайкам К.Э. и др. Охрана окружающей среды в России: Статистический сборник. - М.: Росстат, 2018. - 125 с.

15. Перспективы использования торфа и продуктов его переработки в коммунальной энергетике сельских и отдаленных районов / Е.А. Медведева, Ю.Н. Женихов, И.В. Урванцев, В.Е Цыба // Теплоэнергетика. - 2017. - № 6. - С. 14-21.

16. Михайлов А.В. Развитие глобального рынка торфа // Труды Инсторфа. - 2018. - № 18 (71) - - С. 3-7.

17. Паников Н.С. Таежные болота - глобальный источник атмосферного метана // Природа. - 1995. - № 6. - С. 14-25.

18. Deep peat warming increases surface methane and carbon dioxide emissions in a black spruce-dominated ombrotrophic bog $/$ A.L. Gill, M-A. Giasson, R. Yu, A.C. Finzi // Global change biology. - 2017. - V. 23. - Iss. 12. - P. 5398-5411.

19. Суворов Г.Г., Чистотин М.В., Сирин А.А. Влияние растительности и режима увлажнения на эмиссию метана из осушенной торфяной почвы // Агрохимия. - 2010. - № 12. - С. 37-45.
Экспериментальная часть по термической переработке биомассы выполнена при поддержке Российского научного фонда (проект № 19-79-00085). Характеристики исходного сырья изучены при поддержке Российского фонда фундаментальных исследований (проект № 18-38-00648). Методика оценки автотермического протекания пиролиза разработана при финансировании Министерства науки и выстего образования РФ (ГЗ Наука 13.13269.2018/8.9) u Томского политехнического университета (ВИУ-НОЦ И.Н. Бутакова-101/2019). Вспомогательные аналитические измерения выполнены на приборной базе ФГБУН ИК СО РАН в рамках государственного задания (проект № AAAA-A17-117041710075-0).

20. Потенциал и возможности использования торфа. Некоммерческое партнерство «Российское торфяное и биоэнергетическое общество». URL: http://rostorf.ru/files/prezentaciya_universal.pdf (дата обращения: 26.08.2019).

21. Родионов В.3. Разработка торфяных месторождений в Ленинградской области (проблемы и решения) // Региональная экология. - 2017. - № 3 (49). - С. 59-64.

22. Получение топливных брикетов из растительной биомассы / Д.Е. Ушаков, Д.В. Карелин, А.Л. Бычков, О.П. Коробейничев, А.Г. Шмаков // Химия твердого топлива. - 2017. - № 4. C. $46-50$.

23. Алехнович А.Н., Богомолов В.В., Артемьева Н.В. Совместное факельное сжигание биомасс с углем // Теплоэнергетика. 2001. - № 2. - С. 26-33.

24. Роддатис К.Ф., Полтарецкий А.Н. Справочник по котельным установкам малой производительности. - М.: Энергоатомиздат, 1989. - 488 с

25. Торф: возгорание торфа, тушение торфяников и торфокомпозиты / Л.Б. Хорошавин, О.А. Медведев, В.А. Беляков, Е.В. Михеева, В.С. Руднов. - М.: МЧС России. ФГБУ ВНИИ ГОЧС (ФЦ), 2013. - $256 \mathrm{c}$.

26. Штин С.М. Применение торфа как топлива для малой энергетики // Горный информационно-аналитический бюллетень. 2011. - № 7. - C. 82-96.

27. Mostafa F. Process optimization of gasification of peat // Modern problems of science and education. - 2015. - V. 1-2. - P. 1-7.

28. Боднар Л.А., Ткаченко С.И., Дахновская О.В. Проблемы сжигания низкосортного топлива в котлах малой мощности // Научные труды Винницкого национального технического университета. - 2012. - № 4. - С. 1-7.

29. Гашо Е.Г., Пузаков В.С., Степанова М.В. Резервы и приоритеты теплоэнергоснабжения российских городов в современных условиях. - М.: ИНП РАН, 2015. - 97 с.

30. Чайка Л.В. Региональное управление развитием систем энергоснабжения европейского севера России // Энергетическая политика. - 2016. - № 5. - С. 35-43.

31. Чаплыгина М.А., Белоусов Р.С. Мировой опыт автономного энергоснабжения для российской глубинки // Аллея науки. 2017. - T. 2. - № 16. - C. 464-474.

32. Мохирев А.П., Безруких Ю.А., Медведев С.О. Переработка древесных отходов предприятий лесопромышленного комплекса, как фактор устойчивого природопользования // Инженерный вестник Дона. - 2015. - № 2. - Ч. 2. - С. 1-13.

33. Recent developments in biomass pelletization - a review / W. Stelte, A.R. Sanadi, L. Shang, J.K. Holm, J. Ahrenfeldt, U.B. Henriksen // Bioresources. - 2012. - V. 7. - № 3. - P. 4451-4490.

34. Kan T., Strezov V., Evans T.J. Lignocellulosic biomass pyrolysis: a review of product properties and effects of pyrolysis parameters // Renewable and Sustainable Energy Reviews. - 2016. - V. 57. P. 1126-1140.

35. Thermal enrichment of different types of biomass by lowtemperature pyrolysis / R.B. Tabakaev, K.T. Ibraeva, A.V. Astafev, Yu.V. Dubinin, N.A. Yazykov, A.S. Zavorin, V.A. Yakovlev // Fuel. - 2019. - V. 245. - P. 29-38.

36. Получение газообразных продуктов при пиролизе биомассы микроводорослей / Н.И. Чернова, С.В. Киселева, О.М. Ларина, Г.А. Сычев // Альтернативная энергетика и экология. - 2018. № 31-36. - C. 23-34 
37. Mohan D., Pittman C.U., Steele P.H. Pyrolysis of wood/biomass for bio-oil: a critical review // Energy \& Fuels. - 2006. - V. 20. № 3. - P. 848-889.

38. TG-FTIR-MS study of pyrolysis products evolving from peat J.L. Yang, H.X. Chen, W.T. Zhao, J.J. Zhou // Journal of analytical and applied pyrolysis. - 2016. - V. 117. - P. 296-309.

39. Перспективы энерготехнологического использования биомассы в Беларуси / И.И. Лиштван, В.М. Дударчик, В.М. Крайко, Е.В. Ануфриева, Е.А. Смолячкова // Химия твердого топлива. - 2017. - № 5. - С. 15-23.

40. Tripathi M., Sahu J.N., Ganesan P. Effect of process parameters on production of biochar from biomass waste through pyrolysis // Renewable and Sustainable Energy Reviews. - 2016. - V. 55. P. 467-481.

41. Influence of pyrolysis temperature on biochar property and function as a heavy metal sorbent in soil / M. Uchimiya, L.H. Wartelle, K.T. Klasson, C.A. Fortier, I.M. Lima // Journal of agricultural and food chemistry. - 2011. - V. 59. - № 6. - P. 2501-2510

42. Влияние модификаторов на структурные особенности углеродсодержащих композиционных материалов при карбонизациии древесины сосны / С.И. Цыганова, Е.В. Мазурова, Г.Н. Бондаренко, О.Ю. Фетисова // Химия растительного сырья. -2016 . - № 4. - С. 143-150.

43. Thermal processing of biomass into high-calorific solid composite fuel / R.B. Tabakaev, I.I. Shanenkov, A.V. Kazakov, A.S. Zavorin // Journal of analytical and applied pyrolysis. - 2017. - V. 124. P. 94-102.

44. Башкиров В.Н., Бикбулатова Г.М., Гатауллина А.А. Перспективы промышленного использования жидких продуктов быстрого пиролиза растительной биомассы // Евразийское научное объединение. - 2018. - № 12-3 (46). - С. 207-210.

45. Simultaneous SOx/NOx emission control with Biolime ${ }^{\mathrm{TM}}$ derived from biomass pyrolysis oil / K.H. Oehr, J. Zhou, G.A. Simons, M. Wójtowicz // Developments in thermochemical biomass conversion. - 1997. - V. 1-2. - P. 1477-1481.

46. Таймаров М.А., Лавирко Ю.В. Теплогенерирующий агрегат с выработкой пиролизного газа // Известия КГАСУ. - 2017. № 3 (41). - С. 158-166.

47. Левин Э.Д. Причины, обуславливающие знак и величину теплового эффекта пиролиза древесины // Химия древесины. 1969. - № 4. - C. 143-148.

48. Геоинформационная система «Возобновляемые источники энергии в Томской области». URL: http:/green.tsu.ru/tomres (дата обращения: 20.08.2019).

49. Formation of charcoal from biomass in a sealed reactor W.S.L. Mok, M.G. Antal, P. Szabo, G. Varhegyi, B. Zelei // Industrial \& Engineering Chemistry. - 1992. - V. 31. - P. 1162 1166.

50. Thermal effects during biomass pyrolysis / L. Basile, A. Tugnoli, C. Stramigioli, V. Cozzani // Thermochimica Acta. - 2016. V. 636 - P. $63-70$

51. Исследование тепловых эффектов пиролиза соломы для оценки возможности его реализации в автотермическом режиме А.В. Астафьев, Р.Б. Табакаев, Д.Е. Мусафиров, А.С. Заворин, Ю.В. Дубинин, Н.А. Языков, В.А. Яковлев // Химия растительного сырья. - 2019. - № 2. - С. 271-280.
52. Кулеш Р.Н. Тепломассоперенос при зажигании и горении массива торфа: автореф. дис. ... канд. техн. наук. - Томск, 2010. $-19 \mathrm{c}$.

53. Heat capacity measurements of various biomass types and pyrolysis residues / C. Dupont, R. Chiriac, G. Gauthier, F. Toche // Fuel. - 2014. - V. 115. - P. 644-651.

54. Кафедра ЮНЕСКО «Энергосбережение и возобновляемые подходы энергии». Топливо и его использование. URL: https://en.ppt-online.org/304929 (дата обращения: 27.08.2019).

55. Кикоин И.К. Таблицы физических величин. Справочник. - М.: Атомиздат, 1976. $-1008 \mathrm{c}$.

56. Термодинамические свойства неорганических веществ / У.Д. Верятин, В.П. Маширев, Н.Г. Рябцев, В.И. Тарасов. - М.: Атомиздат, 1965. - $461 \mathrm{c}$.

57. Тепловыделение при горении древесины / Б.Б. Серков, А.Б. Сивенков, Д.Т. Буй, Р.М. Асеева // Вестник Московского государственного университета леса - Лесной вестник. 2003. - № 5. - C. 74-79.

58. Архипов В.С., Маслов С.Г. Состав и свойства типичных видов торфа центральной части Западной Сибири // Химия растительного сырья. - 1998. - № 4. - С. 9-16.

59. Autothermal pyrolysis of biomass due to intrinsic thermal decomposition effects / A.V. Astafev, R.B. Tabakaev, Yu.V. Dubinin, N.A. Yazykov, V.A. Yakovlev, A.S. Zavorin // Journal of thermal analysis and calorimetry. - 2018. - V. 134. - № 2. P. $1045-1057$.

60. Demirbas A. Mechanisms of liquefaction and pyrolysis reactions of biomass // Energy Conversion \& Management. - 2000. V. 41. - P. 633-646.

61. Characteristics of hemicellulose, cellulose and lignin pyrolysis / H. Yang, R. Yan, H. Chen, D.H. Lee, C. Zheng // Fuel. - 2007. V. 86. - P. 1781-1788.

62. Ларина Г.В., Иванов А.А., Казанцева Н.А. Групповой состав органического вещества торфов Горного Алтая и некоторые структурные характеристики гуминовых кислот // Вестник ТГПУ. - 2009. - № 3 (81). - С. 110-115.

63. Чухарева Н.В. Исследование группового состава торфов месторождений Томской области // Вестник КрасГАУ. - 2013. № 7. - С. $65-71$.

64. Лобзин В.И., Смольянинов С.И. Некоторые особенности термического разложения торфа // Известия Томского политехнического института. - 1974. - Т. 198. - С. 38-40.

65. Бородина Т.А., Дроздова Н.А. Состояние торфяных ресурсов Томской области и направления их использования в сельском хозяйстве // Проблемы современной аграрной науки: материалы международной заочной научной конференции. - Красноярск: КГАУ, 2017. - С. 104-108.

66. Процесс пиролиза биомассы как источник получения альтернативного топлива / В.М. Капустин, Е.А. Чернышева, Ю.В. Кожевникова, В.Ю. Асаула // Технологии нефти и газа. 2011. - № 3 (74). - C. 31-35.

67. Characterization of Singapore RDF resources and analysis of their heating value / L. Zhao, A. Giannis et al. // Sustainable Environment Research. - 2016. - V. 26. - P. 51-54.

Поступила 02.12.2019 г.

\section{Информация об авторах}

Aстафьев A.B., аспирант научно-образовательного центра И.Н. Бутакова Инженерной школы энергетики Национального исследовательского Томского политехнического университета.

Tабакаев P.Б., кандидат технических наук, научный сотрудник научно-образовательного центра И.Н. Бутакова Инженерной школы энергетики Национального исследовательского Томского политехнического университета.

Языков Н.A., кандидат технических наук, научный сотрудник лаборатории каталитических процессов переработки возобновляемого сырья Института катализа им. Г.К. Борескова СО РАН.

Заворин A.C., доктор технических наук, заведующий кафедрой - руководитель научно-образовательного центра И.Н. Бутакова на правах кафедры Инженерной школы энергетики Национального исследовательского Томского политехнического университета 
UDC 662.638

\title{
THERMOPHYSICAL SUBSTANTIATION OF RENEWABLE BIOMASS PYROLYTIC PROCESSING DUE TO HEAT DECOMPOSITION
}

\author{
Alexander V. Astafev 1 , \\ ava31@tpu.ru \\ Roman B. Tabakaev ${ }^{1}$, \\ TabakaevRB@tpu.ru \\ Nikolay A. Yazykov², \\ yazykov@catalysis.ru
}

\author{
Alexander S. Zavorin ${ }^{1}$, \\ Zavorin@tpu.ru \\ 1 National Research Tomsk Polytechnic University, \\ 30, Lenin avenue, Tomsk, 634050, Russia. \\ 2 Boreskov Institute of Catalysis SB RAS, \\ 5, Acad. Lavrentiev avenue, Novosibirsk, 630090, Russia.
}

The relevance of the research is caused by the need of renewable energy sources share increase in the fuel and energy balance to reduce harmful impact on the environment.

The main aim of the research is to evaluate the possibility of woody biomass and peat pyrolysis due to heat from the organic part decomposition of the raw material.

Objects: peat samples from two deposits of the Tomsk region, promising for energy development, - Sukhovsky and Arkadievsky, as well as wood waste of two types - chips and sawdust.

Methods: physical experiment and differential thermal analysis. Thermotechnical characteristics of woody biomass determined by the methods SS R 56881-2016, SS 33503-2015 and SS R 55660-2013; thermal characteristics of peat - using the SS 11306-2013, SS 11305-2013 and SS R 55660-2013. Calorific value of raw materials determined in the bomb calorimeter ABK-1 (RET, Russia), the elemental composition is determined by the analyser Vario Micro Cube (Elementar, Germany) taking into account the carbon dioxide content of the carbonates, established by volumetric method according to SS 13455-91.

Results. The authors have established the optimal parameters of pyrolytic processing for various types of biomass, such as pyrolysis temperature and moisture of the raw material. The optimum temperature for pyrolysis of wood waste in the air-dry state is $400^{\circ} \mathrm{C}$, at which the total thermal effect is maximum and equal to $36,3 \mathrm{~kJ} / \mathrm{kg}$ for sawdust and $78,8 \mathrm{~kJ} / \mathrm{kg}$ for wood chips, for sukhovskoy peat at $500{ }^{\circ} \mathrm{C}$ total heat effect is equal to $149,7 \mathrm{~kJ} / \mathrm{kg}$. The maximum values of moisture, providing coverage of heat costs due to the heat of exothermic reactions, at these pyrolysis temperatures were $10 \%$ for wood waste and $14 \%$ for sukhovskoy peat. The value of the total thermal effect of arkadievsky peat pyrolysis even in the dry state has a negative value.

Key words:

Biomass, thermal processing, exothermic reactions, thermal effect, cellulose, lignin.

The experimental part on biomass thermal processing was supported by the Russian Science Foundation (project No. 19-79-00085). The characteristics of the feedstock were studied with the support of the Russian Foundation for Basic Research (project No. 18-38-00648). The methodology for assessing the autothermal course of pyrolysis was developed with the funding of the Ministry of Science and Higher Education of the Russian Federation (State Science Nauka 13.13269.2018 / 8.9) and Tomsk Polytechnic University (VIU-SEC I.N. Butakova-101/2019). Auxiliary analytical measurements were performed on the instrument base of the Federal State Budgetary Institution IR SB RAS within the framework of the state assignment (project No. AAAA-A17-117041710075-0).

\section{REFERENCES}

1. World Energy Outlook Special Report. Energy and Air Pollution. Paris, International Energy Agency Publ., 2016. 9 p.

2. Matthews H.D., Gillett N.P., Stott P.A., Zickfeld K. The proportionality of global warming to cumulative carbon emissions. Nature, 2009, vol. 459, pp. 829-832.

3. Sidorovich V. Mirovaya energeticheskaya revolyutsiya. Kak vozobnovlyaemye istochniki energii izmenyat nash mir [World energy revolution. How renewables will change our world]. Moscow, Alpina Publ., 2015. 208 p.

4. Popel O.S., Fortov V.E. Vozobnovlyaemaya energetika $v$ sovremennom mire [Renewable energy in the modern world]. Moscow, MPEI Publ. house, 2015. 450 p.
5. Statistics of International Energy Agency. Available at: https://www.iea.org/statistics/?country=WORLD\&year=2016\&cat egory $=$ Energy $\% 20$ supply\&indicator $=$ TPESbySource $\&$ mode $=$ chart\&dataTable=BALANCES (accessed 23 August 2019).

6. Timokhov V.M., Zhiznin S.Z. Resources of world energy. Herald of Moscow Humanitarian Economic University, 2018, no. 2, pp. 115-124. In Rus.

7. Ermolenko G.V. Spravochnik po vozobnovlyaemoy energetike evropeyskogo soyuza [Handbook of renewable energy of the European Union]. Moscow, HSE Institute of energy Publ., 2016. $96 \mathrm{p}$.

8. Dhyani V., Bhaskar T. A comprehensive review on the pyrolysis of lignocellulosic biomass. Renewable energy, 2018, vol. 129, pp. $695-716$. 
9. Saidur R., Abdelaziz E.A., Demirbas A., Hossaina M.S., Mekhilef S A review on biomass as a fuel for boilers. Renewable and sustainable energy reviews, 2011, vol. 15, pp. 2262-2289.

10. Vassilev S.V., Baxter D., Andersen L.K., Vassileva C.G. An overview of the chemical composition of biomass. Fuel, 2010, vol. 89, pp. 913-933.

11. McKendry P. Energy production from biomass. P. 1: overview of biomass. Bioresource Technology, 2002, vol. 83, pp. 37-46.

12. Terenteva E.P., Udovenko N.K., Pavlova E.A. Kompleksnaya khimicheskaya pererabotka drevesiny [Complex chemical processing of wood]. St-Petersburg, VSTA Spbgutd Publ., 2016. $74 \mathrm{p}$.

13. Vafina Yu.A. Energy saving through the use of alternative energy sources and secondary energy resources: Russia and world experience. Herald of Kazan technological University, 2012, vol. 15 , no. 9, pp. 265-272. In Rus.

14. Laykam K.E. Okhrana okruzhayushchey sredy $v$ Rossii: statisticheskiy sbornik [Environmental protection in Russia: statistical compendium]. Moscow, Rosstat Publ., 2018. 125 p.

15. Medvedeva E.A., Zhenikhov Yu.N., Urvantsev I.V., Tsyba V.E. Prospects for using peat and products of its processing in municipal power engineering in rural and remote areas. Thermal Engineering, 2017, no. 6, pp. 14-21. In Rus.

16. Mikhaylov A.V. Global peat market development. Proceedings of the peat Institute, 2018, no. 18 (71), pp. 3-7. In Rus.

17. Panikov N.S. Taezhnye bolota - globalny istochnik atmosfernogo metana [Taiga swamps are a global source of atmospheric methane]. Priroda, 1995, no. 6, pp. 14-25.

18. Gill A.L., Giasson M-A., Yu R., Finzi A.C. Deep peat warming increases surface methane and carbon dioxide emissions in a black spruce-dominated ombrotrophic bog. Global change biology, 2017 vol. 23, Iss. 12, pp. 5398-5411.

19. Suvorov G.G., Chistotin M.V., Sirin A.A. Effect of vegetation and moisture conditions on the emission of methane from drained peat soil. Agrochemistry, 2010, no. 12, pp. 37-45. In Rus.

20. Potentsial i vozmozhnosti ispolzovaniva torfa. Nekommercheskoe partnerstvo "Rossiyskoe torfyanoe $i$ bioenergeticheskoe obshchestvo» [Potential and possibilities of peat use. Non-profit partnership «Russian peat and bioenergy society»]. Available at: http://rostorf.ru/files/prezentaciya universal.pdf (accessed 26 August 2019).

21. Rodionov V.Z. Development of peat deposits in the Leningrad oblast: problems and solutions. Regional ecology, 2017, no. 3 (49), pp. 59-64. In Rus.

22. Ushakov D.E., Karelin D.V., Bychkov A.L., Korobeynichev O.P., Shmakov A.G. Poluchenie toplivnykh briketov iz rastitelnoy biomassy [Production of fuel briquettes from plant biomass]. Khimiva tverdogo topliva, 2017, no. 4, pp. 46-50.

23. Alekhnovich A.N., Bogomolov V.V., Artemeva N.V. Co-flaring of biomass with coal. Thermal Engineering, 2001, no. 2, pp. 26-33. In Rus.

24. Roddatis K.F., Poltaretskiy A.N. Spravochnik po kotelnym ustanovkam maloy proizvoditelnosti [Handbook of small capacity boiler plants]. Moscow, Energoatomizdat Publ., 1989. 488 p.

25. Khoroshavin L.B., Medvedev O.A., Belyakov V.A., Mikheeva E.V., Rudnov V.S. Torf: vozgoranie torfa, tushenie torfyanikov $i$ torfokompozity [Peat: a peat fire, a suppression of peat and tivocommunity]. Moscow, EMERCOM of Russia, 2013. $256 \mathrm{p}$.

26. Shtin S.M. Primenenie torfa kak topliva dlya maloj energetiki [The use of peat as a fuel for small energy]. Gorny informatsionnoanaliticheskiy byulleten, 2011, no. 7, pp. 82-96.

27. Mostafa F. Process optimization of gasification of peat. Modern problems of science and education, 2015, vol. 1-2, pp. 1-7.

28. Bodnar L.A., Tkachenko S.I., Dakhnovskaya O.V. Problemy szhiganiya nizkosortnogo topliva $\mathrm{v}$ kotlakh maloy moshchnosti [Problems of low-grade fuel combustion in low-power boilers] Nauchnye trudy vinnitskogo natsionalnogo tekhnicheskogo universiteta, 2012, no. 4, pp. 1-7.

29. Gasho E.G., Puzakov V.S., Stepanova M.V. Rezervy i prioritety teploenergosnabzheniya rossiyskikh gorodov $v$ sovremennykh usloviyakh [Reserves and priorities of heat supply of Russian cities in modern conditions]. Moscow, INEF RAS Publ., 2015. 97 p.

30. Chayka L.V. Regional management of energy supply systems development in the European North of Russia. Energy policy, 2016, no. 5, pp. 35-43. In Rus.

31. Chaplygina M.A., Belousov R.S. World experience of autonomous power supply for the Russian hinterland. Alley science, 2017, vol. 2, no. 16, pp. 464-474. In Rus.

32. Mokhirev A.P., Bezrukikh Yu.A., Medvedev S.O. Pererabotka drevesnykh otkhodov predpriyatiy lesopromyshlennogo kompleksa, kak faktor ustoychivogo prirodopolzovaniya [Processing of wood waste of the timber industry enterprises as a factor of sustainable nature management]. Inzhenerny vestnik Dona, 2015, no. 2, P. 2, pp. 1-13.

33. Stelte W., Sanadi A.R., Shang L., Holm J.K., Ahrenfeldt J., Henriksen U.B. Recent developments in biomass pelletization - a review. Bioresources, 2012, vol. 7, no. 3. pp. 4451-4490.

34. Kan T., Strezov V., Evans T.J. Lignocellulosic biomass pyrolysis: a review of product properties and effects of pyrolysis parameters. Renewable and Sustainable Energy Reviews, 2016, vol. 57, pp. 1126-1140.

35. Tabakaev R.B., Ibraeva K.T., Astafev A.V., Dubinin Yu.V., Yazykov N.A., Zavorin A.S., Yakovlev V.A. Thermal enrichment of different types of biomass by low-temperature pyrolysis. Fuel, 2019, vol. 245, pp. 29-38.

36. Chernova N.I., Kiseleva S.V., Larina O.M., Sychev G.A. Production of gaseous products during pyrolysis of microalgae biomass. Alternative energy and ecology, 2018, no. 31-36, pp. 23-34. In Rus.

37. Mohan D., Pittman C.U., Steele P.H. Pyrolysis of wood/biomass for bio-oil: a critical review. Energy \& Fuels, 2006, vol. 20, no. 3, pp. 848-889.

38. Yang J.L., Chen H.X., Zhao W.T., Zhou J.J. TG-FTIR-MS study of pyrolysis products evolving from peat. Journal of analytical and applied pyrolysis, 2016, vol. 117, pp. 296-309.

39. Lishtvan I.I., Dudarchik V.M., Krayko V.M., Anufrieva E.V., Smolyachkova E.A. Perspektivy energotekhnologicheskogo ispolzovaniya biomassy $\mathrm{v}$ Belarusi [Prospects of energy and technological use of biomass in Belarus]. Khimiya tverdogo topliva, 2017, no. 5, pp. 15-23.

40. Tripathi M., Sahu J.N., Ganesan P. Effect of process parameters on production of biochar from biomass waste through pyrolysis. Renewable and Sustainable Energy Reviews, 2016, vol. 55, pp. 467-481.

41. Uchimiya M., Wartelle L.H., Klasson K.T., Fortier C.A., Lima I.M. Influence of pyrolysis temperature on biochar property and function as a heavy metal sorbent in soil. Journal of agricultural and food chemistry, 2011, vol. 59, no. 6, pp. 2501-2510.

42. Tsyganova S.I., Mazurova E.V., Bondarenko G.N., Fetisova O.Yu. Effect of modifiers on the structural features of carbonaceous composite during carbonization of pine wood. Chemistry of plant raw material, 2016, no. 4, pp. 143-150. In Rus.

43. Tabakaev R.B., Shanenkov I.I., Kazakov A.V., Zavorin A.S. Thermal processing of biomass into high-calorific solid composite fuel. Journal of analytical and applied pyrolysis, 2017, vol. 124, pp. $94-102$.

44. Bashkirov V.N., Bikbulatova G.M., Gataullina A.A. Perspektivy promyshlennogo ispolzovaniya zhidkikh produktov bystrogo piroliza rastitelnoy biomassy [Prospects of industrial use of liquid products of fast pyrolysis of plant biomass]. Evraziyskoe nauchnoe obedinenie, 2018, no. 12-3 (46), pp. 207-210.

45. Oehr K.H., Zhou J., Simons G.A., Wójtowicz M. Simultaneous SOx/NOx emission control with Biolime ${ }^{\mathrm{TM}}$ derived from biomass pyrolysis oil. Developments in thermochemical biomass conversion, 1997, vol. 1-2, pp. 1477-1481.

46. Taymarov M.A., Lavirko Yu.V. The heat generating unit with the pyrolysis gas generation. News of KSUAE, 2017, no. 3 (41), pp. 158-166. In Rus

47. Levin E.D. Prichiny, obuslavlivayushchie znak i velichinu teplovogo effekta piroliza drevesiny [The reasons for the sign and magnitude of the thermal effect of pyrolysis of wood]. Khimiya drevesiny, 1969, no. 4, pp. 143-148. 
48. Geoinformatsionnaya sistema "Vozobnovlyaemye istochniki energii v Tomskoy oblasti» [Geoinformation system «Renewable energy sources in Tomsk region»]. Available at: http://green.tsu.ru/tomres (accessed 20 August 2019).

49. Mok W.S.L., Antal M.G., Szabo P., Varhegyi G., Zelei B. Formation of charcoal from biomass in a sealed reactor. Industrial \& Engineering Chemistry, 1992, vol. 31, pp. 1162-1166.

50. Basile L., Tugnoli A., Stramigioli C., Cozzani V. Thermal effects during biomass pyrolysis. Thermochimica Acta, 2016, vol. 636, pp. 63-70.

51. Astafev A.V., Tabakaev R.B., Musafirov D.E., Zavorin A.S., Dubinin Yu.V., Yazykov N.A., Yakovlev V.A. Research of straw pyrolysis thermal effects for estimation of possibility its implementation in autothermal mode. Chemistry of plant raw material, 2019, no. 2, pp. 271-280. In Rus.

52. Kulesh R.N. Teplomassoperenos pri zazhiganii i gorenii massiva torfa. Avtoreferat Dis. Kand. nauk [Heat and mass transfer during ignition and burning of peat massif. Cand. Diss. Abstract]. Tomsk, 2010. 19 p.

53. Dupont C., Chiriac R., Gauthier G., Toche F. Heat capacity measurements of various biomass types and pyrolysis residues. Fuel, 2014, vol. 115, pp. 644-651.

54. Kafedra YUNESKO "Energosberezhenie $i$ vozobnovlyaemye podkhody energii». Toplivo $i$ ego ispolzovanie [UNESCO academic chair «Energy saving and renewable energy approaches». Fuel and its use]. Available at: https://en.ppt-online.org/304929 (accessed 27 August 2019).

55. Kikoin I.K. Tablitsy fizicheskikh velichin. Spravochnik [Tables of physical quantities. A handbook]. Moscow, Atomizdat Publ., 1976. $1008 \mathrm{p}$.

56. Veryatin U.D. Termodinamicheskie svoystva neorganicheskikh veshchestv [Thermodynamic properties of inorganic substances]. Moscow, Atomizdat Publ., 1965. 461 p.

57. Serkov B.B., Sivenkov A.B., Buy D.T., Aseeva P.M. Teplovydelenie pri gorenii drevesiny [The generated heat of burning wood]. Vestnik moskovskogo gosudarstvennogo universiteta lesa - Lesnoy vestnik, 2003, no. 5, pp. 74-79.
58. Arkhipov V.S., Maslov S.G. Composition and properties of typical peat species in the Central part of Western Siberia. Chemistry of plant raw material, 1998, no. 4, pp. 9-16. In Rus.

59. Astafev A.V., Tabakaev R.B., Dubinin Y.V., Yazykov N.A., Yakovlev V.A., Zavorin A.S. Autothermal pyrolysis of biomass due to intrinsic thermal decomposition effects. Journal of thermal analysis and calorimetry, 2018, vol. 134, №. 2. pp. 1045-1057.

60. Demirbas A. Mechanisms of liquefaction and pyrolysis reactions of biomass. Energy Conversion \& Management, 2000, vol. 41, pp. 633-646.

61. Yang H., Yan R., Chen H., Lee D.H., Zheng C. Characteristics of hemicellulose, cellulose and lignin pyrolysis. Fuel, 2007, vol. 86, pp. 1781-1788.

62. Larina G.V., Ivanov A.A., Kazantseva N.A. The group structure of organic substances of peats of Gorny Altai and something structural characteristics of humic acids. TSPU Bulletin, 2009, no. 3 (81), pp. 110-115. In Rus.

63. Chukhareva N.V. The research of peat group composition in Tomsk region deposits. Bulletin of KrasSAU, 2013, no. 7, pp. 65-71. In Rus.

64. Lobzin V.I., Smolyaninov S.I. Some features of thermal peat decomposition. Bulletin of TPI, 1974, vol. 198, pp. 38-40. In Rus.

65. Borodina T.A., Drozdova N.A. Sostoyanie torfyanykh resursov Tomskoy oblasti i napravleniya ikh ispolzovaniya $\mathrm{v}$ selskom khozyaystve [State of peat resources of Tomsk region and directions of their use in agriculture]. Problemy sovremennoy agrarnoy nauki. Materialy mezhdunarodnoy zaochnoy nauchnoy konferentsii [Problems of modern agricultural science. Proc. of the international correspondence scientific conference]. Krasnoyarsk, KSAU Publ., 2017. pp. 104-108.

66. Kapustin V.M., Chernysheva E.A., Kozhevnikova Yu.V., Asaula V.Yu. Biomass pyrolysis process as a source for alternative fuel. Oil and gas technologies, 2011, no. 3 (74), pp. 31-35. In Rus.

67. Zhao L., Giannis A. Characterization of Singapore RDF resources and analysis of their heating value. Sustainable Environment Research, 2016, vol. 26, pp. 51-54.

Received: 2 December 2019.

\section{Information about the authors}

Alexander $\boldsymbol{V}$. Astafev, postgraduate student, National Research Tomsk Polytechnic University.

Roman B. Tabakaev, Cand. Sc., researcher, National Research Tomsk Polytechnic University.

Nikolay A. Yazykov, Cand. Sc., researcher, Boreskov Institute of Catalysis SB RAS.

Alexander S. Zavorin, Dr. Sc., professor, National Research Tomsk Polytechnic University. 